\title{
Seasonal variations, metal distribution and water quality in the Todos os Santos River, Southeastern Brazil: a multivariate analysis
}

\author{
CLÁUdiA A.F. PEREIRA ${ }^{1}$, LUIZ F.O. MAIA ${ }^{1}$, MÁRCIA C.S. FARIA ${ }^{1}$, PAULO H. FIDÊNCIO ${ }^{2}$, \\ CLEIDE A. BOMFETI ${ }^{1}$, FERNANDO BARBOSA JUNIOR ${ }^{3}$ and JAIRO L. RODRIGUES ${ }^{1}$ \\ ${ }^{1}$ Instituto de Ciência, Engenharia e Tecnologia, Universidade Federal dos Vales do Jequitinhonha \\ e Mucuri, Rua do Cruzeiro, 01, 39803-371 Teófilo Otoni, MG, Brazil \\ ${ }^{2}$ Faculdade de Ciências Exatas e Tecnológicas, Universidade Federal dos Vales do Jequitinhonha \\ e Mucuri, Avenida Diamantina, s/n, 39100-000 Diamantina, MG, Brazil \\ ${ }^{3}$ Faculdade de Ciências Farmacêuticas de Ribeirão Preto, Universidade de São Paulo, \\ Avenida do Café, s/n, 14040-903 Ribeirão Preto, SP, Brazil
}

Manuscript received on June 5, 2017; accepted for publication on April 4, 2018

\begin{abstract}
In aquatic habitats, metal contamination from natural and anthropogenic sources continues to pose a concern for human and environmental health. Thus, it is important to complete monitoring studies to assess patterns and the extent of metal contamination in these ecosystems. The purpose of this work was to determine the concentrations of 31 chemical elements and water quality parameters of the Todos os Santos River located in the Mucuri Valley, Minas Gerais, Brazil. A multivariate statistical analysis was used to determine any seasonal and spatial patterns from the data. Results demonstrated that metals including $\mathrm{Al}, \mathrm{Fe}$, and $\mathrm{Ni}$ exceeded Brazilian and international guidelines nutrients as $\mathrm{P}$ also exceed water quality standards. Principal components analysis indicated distinct geographical and seasonal patterns for multiple elements with hierarchical cluster analysis confirming the observed spatial patterns of contamination in the Todos os Santos River.
\end{abstract}

Key words: toxic pollutants, metals, water quality, environment.

\section{INTRODUCTION}

Anthropogenic activities carried out in urban and rural areas generate pollutants that are usually discharged into rivers without prior treatment. These activities include industrial activities, use of pesticides, fertilizers, and manures. Rivers, lakes, and seas have received large amounts of wastewater from domestic and industrial sources,

Correspondence to: Jairo Lisboa Rodrigues

E-mail: jairo.rodrigues@ufvjm.edu.br thus endangering the living beings that use these water resources on a daily basis (Ohe et al. 2004, Jordão et al. 2007). Therefore, water bodies may be contaminated with complex, ill-defined mixtures of chemicals and most freshwater organisms will be exposed, to varying degrees, to this contamination (Scalon et al. 2013). The toxic elements produced are relocated by the action of rain, contaminating soils and waterways that surround these areas (Ren et al. 2004, Rezende et al. 2011). 
Among the contaminants present in waters, metals stand out. In aquatic environments, metals may come from various natural and anthropogenic sources, such as atmospheric deposition, geological weathering, agricultural activities and residential and industrial products (Weber et al. 2013). High concentrations of these pollutants have been demonstrated to cause adverse effects in the human body, such as heart and neurological problems and skin cancer, affecting many ecosystems (Chiba et al. 2011, Chang and Ling 2014). The Todos os Santos River (TSR) is located in Teófilo Otoni (Mucuri Valley, Minas Gerais State, Brazil). This water system receives a waste discharge of various origins, especially in parts of the river that run through urban areas. However, there are few studies on the environmental conditions of this river and the possible types of contamination that could lead to health risks for the local populations. Recently, a study conducted by Blanc et al. 2014 at the Todos os Santos River pointed out concentrations of aluminum, phosphorus, and iron above the maximum levels permitted by Brazilian law (CONAMA 2005) and the World Health Organization (WHO 2004).

The objective of the present study was to determine the metal concentrations, physical and chemical parameters in TSR water samples during periods of rain and drought, to assess spatial and temporal patterns in water quality using multivariate statistical analyses.

\section{MATERIALS AND METHODS}

Samples were taken over a period of eight months in 2012, comprising periods of drought, which include the months from May to September, and the rainy season, which lasts from October to December. Two points are located upstream the selected urban area and near the source of the river (points 1 and 2); two other points are located downstream the urban area (points 5 and 6), and two are located within the urban area, which is in a region with severe contamination (points 3 and 4). At each sample site, about $1 \mathrm{~L}$ of water was collected according to the CETESB standards (CETESB 2012), using metal-free polypropylene bottles. The samples were stored at $4^{\circ} \mathrm{C}$ until analysis, and a total sample volume of $100 \mathrm{~mL}$ was collected for the physical and chemical analyses.

The geographic coordinates of each point were determined using a Garmin 60CSx GPS receiver. The geographical location and altitude of the sampling sites are $17^{\circ} 50^{\prime} \mathrm{S} 41^{\circ} 40^{\prime} \mathrm{W}$ and $598.4 \mathrm{~m}(\mathrm{P}-1), 1^{\circ} 48^{\prime} \mathrm{S} 41^{\circ} 39^{\prime} \mathrm{W}$ and $550.8 \mathrm{~m}(\mathrm{P}-$

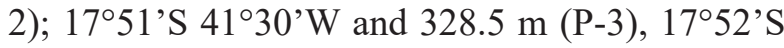

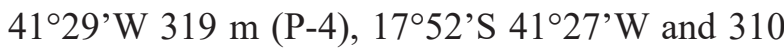
$\mathrm{m}(\mathrm{P}-5)$; 17 $7^{\circ} 52^{\prime} \mathrm{S} 41^{\circ} 18^{\prime} \mathrm{W}$ and $272.5 \mathrm{~m}$ (P-6). The water collection points $(n=6)$ were defined based on several parameters, such as the proximity to urban centers and water use within a radius of 74 km (Fig. 1).

The physical and chemical parameters measured were $\mathrm{pH}$, dissolved oxygen, turbidity, conductivity, and temperature, using a $\mathrm{pH}$-meter (power meter model mPA-210), an oximeter (model DO5519), a turbidimeter (Poly Control, model AP-2000), and a conductivity meter (model $\mathrm{mCA}-150 \mathrm{p}$ ) for conductivity and temperature, respectively. The measurements were made following the instruction manuals of each equipment. The dissolved oxygen, conductivity and temperature were determined in situ, and $\mathrm{pH}$ and turbidity were analyzed in the laboratory. High purity deionized water (resistivity $18.2 \mathrm{M} \Omega \mathrm{cm}$ ) obtained by the Milli-Q system (Millipore ${ }^{\circledR}$ ) was used throughout the study and for preparing the calibration standards.

The determination of metals was performed by an inductively coupled plasma mass spectrometer (ICP-MS, ELAN DRC II, PerkinElmer), according to the method of Lawrence et al. 2006 with modifications. The equipment was installed in a clean room class 1000 in the laboratory of 


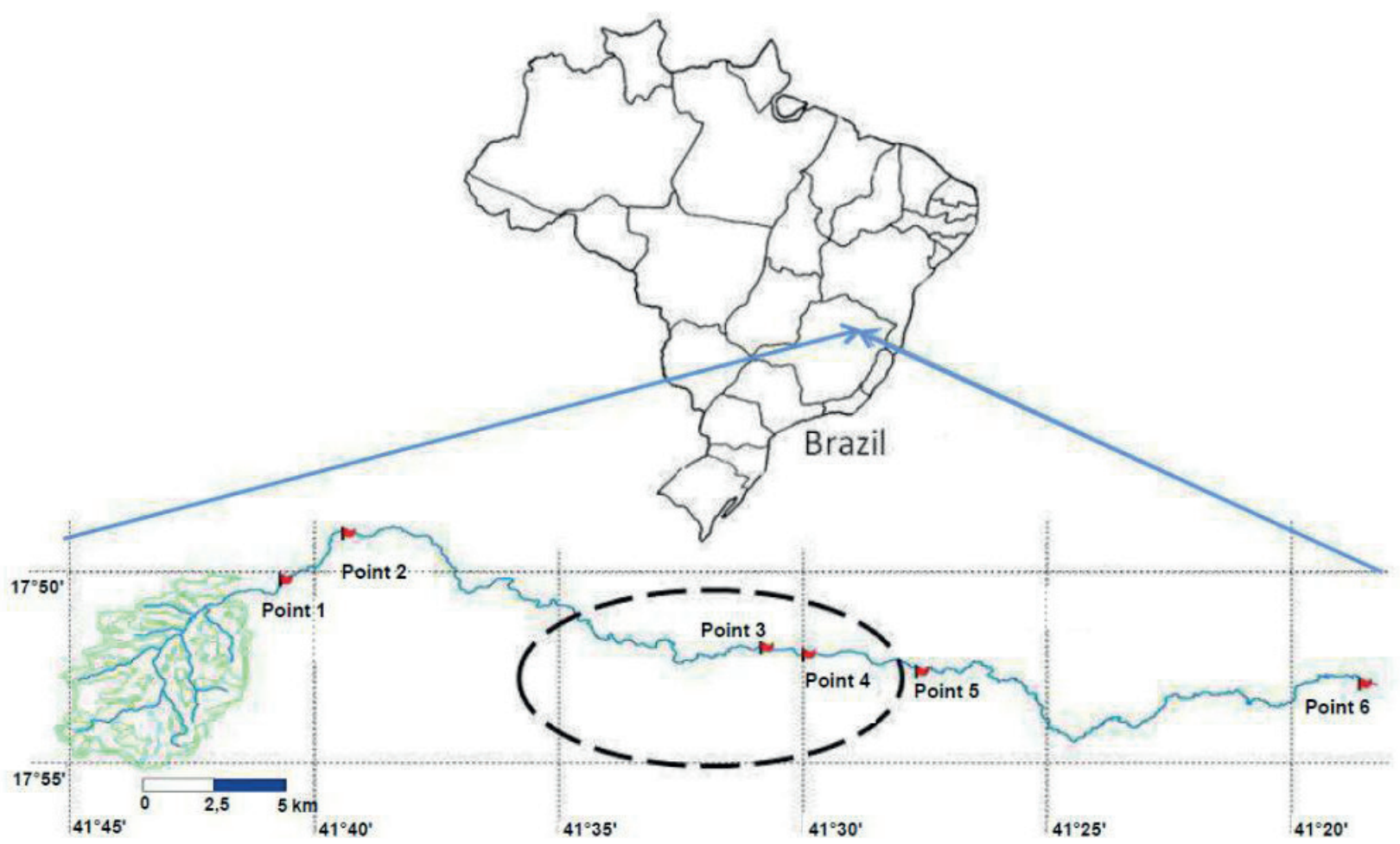

Figure 1 - Points of water samples collected from Todos os Santos River. Point 1 and Pont 2 are located upstream the urban area of Teófilo Otoni city and near the source of the river; points 3 and 4 are located within the urban area, and points 5 and are located downstream the urban area.

toxicology and properties of metals, Universidade de São Paulo (USP-Brazil). The determination of iron $(\mathrm{Fe})$ levels in the collected samples was carried out with a spectrophotometer (Siqueira et al. 2009). For this, we used a spectrophotometer SP-220-Brazil.

The following metals were tested in surface water samples ${ }^{107} \mathrm{Ag},{ }^{27} \mathrm{Al},{ }^{75} \mathrm{As},{ }^{138} \mathrm{Ba},{ }^{9} \mathrm{Be},{ }^{209} \mathrm{Bi}$, ${ }^{44} \mathrm{Ca},{ }^{111} \mathrm{Cd},{ }^{59} \mathrm{Co},{ }^{133} \mathrm{Cs},{ }^{63} \mathrm{Cu},{ }^{69} \mathrm{Ga},{ }^{202} \mathrm{Hg},{ }^{115} \mathrm{In},{ }^{39} \mathrm{~K}$, ${ }^{7} \mathrm{Li},{ }^{55} \mathrm{Mn},{ }^{23} \mathrm{Na},{ }^{60} \mathrm{Ni},{ }^{31} \mathrm{P},{ }^{208} \mathrm{~Pb},{ }^{32} \mathrm{~S},{ }^{82} \mathrm{Se},{ }^{28} \mathrm{Si},{ }^{88} \mathrm{Sr}$, ${ }^{205} \mathrm{Tl},{ }^{238} \mathrm{U},{ }^{51} \mathrm{~V},{ }^{184} \mathrm{~W}$ and ${ }^{66} \mathrm{Zn}$. The limits of detection (LOD) method for these elements were 0.002; 0.005; $0.0002 ; 0.003 ; 0.001 ; 0.01 ; 0.0001 ; 0.001 ; 0.001$; $0.0006 ; 0.01 ; 0.0005 ; 0.009 ; 0.0007 ; 0.05 ; 0.002$; $0.0001 ; 0.005 ; 0.0009 ; 0.4 ; 0.0001 ; 8.0 ; 0.001 ; 0.09$; $0.0002 ; 0.06 ; 0.0001 ; 0.001 ; 0.005$ and $0.0008 \mu \mathrm{g}$ $\mathrm{L}^{-1}$, respectively. For this, were used calibration standard solutions from PerkinElmer (USA).

All reagents used were of analytical quality except high purity $\mathrm{HNO}_{3}$, which was submitted to distillation at a temperature below its boiling point using a Quartz distiller (Kürner). High purity deionized water (resistivity $18.2 \mathrm{M} \Omega . \mathrm{cm}$ ) obtained by the Milli-Q system (Millipore ${ }^{\circledR}$ ) was used throughout the study. Quality control for the determination of metals in the water samples was carried out via analysis of water standard reference materials (Aluminum, Antimony, Arsenic, Barium, Beryllium, Boron, Cadmium, Calcium, Chromium, Cobalt,Copper,Iron,Lead, Magnesium, Manganese, Molybdenum, Nickel, Potassium, Selenium, Silver, Silicon, Sodium, Strontium, Thallium, Uranium, Vanadium, Zinc) from the National Institute of Standards and Technology (NIST 1640, Trace Elements in Natural Water). The reference samples were analyzed before and after ten runs of ordinary water samples. There were no statistical differences between the concentration values obtained for the reference materials and the "target-values" for $95 \%$ confidence intervals using the T-test. In the 
multivariate analysis, the data were arranged in a matrix consisting of variables (columns), such as the concentration of each identified constituent; the objects (rows) were the sampled populations. The matrix was self-scaled before PCA and HCA were performed, the latter using the algorithm of means (Laurence et al. 2006). Data were analyzed using chemometrics software in MATLAB version 5.3 and the package PLS_Toolbox (Version 2.0).

\section{RESULTS AND DISCUSSION}

The average results of physical and chemical analyses in periods of drought and rain are shown in Fig. 2. During the dry period, the $\mathrm{pH}$ ranged from 6.7 to 7.4 , and the turbidity varied between 4.4 and 58 NTU. These values of $\mathrm{pH}$ and turbidity are in agreement with the recommendations by the Resolution 357 of CONAMA/2005 (pH from 6.0 to 9.0 and turbidity until $100 \mathrm{NTU}$ ). The levels of dissolved oxygen (DO) were in disagreement with the resolution at points $\mathrm{P}-3, \mathrm{P}-4$ and $\mathrm{P}-5$, ranging from 2.7 to $6.7 \mathrm{mg} \mathrm{L}^{-1}$.

During the rainy period, the $\mathrm{pH}$ and turbidity ranged from 6.7 to 7.2 and 4.8 to 89 NTU, respectively. The DO values in the rainy period ranged from 2.2 to $6.6 \mathrm{mg} \mathrm{L}^{-1}$; locations $\mathrm{P}-1, \mathrm{P}-4$, and P-6 were below the established minimum value ( $5 \mathrm{mg} \mathrm{L}^{-1} \mathrm{DO}$ ) by the Resolution 357 of CONAMA/2005.

Dissolved oxygen is essential to aquatic life (Jordão et al. 2007), and low values are associated to the presence of oxidable substances, such as biodegradable organic matter and ions of lower oxidation state as Fe (II) and Mn (II) (Von Sperling 1996). This situation can lead to problems for the organisms living in the river because reduced oxygen in the water is not conducive to the survival of aerobic organisms and it is essential for the maintenance of the natural processes (CETESB 2001).

In both seasons, the electrical conductivity of TSR exhibited high values when passing through
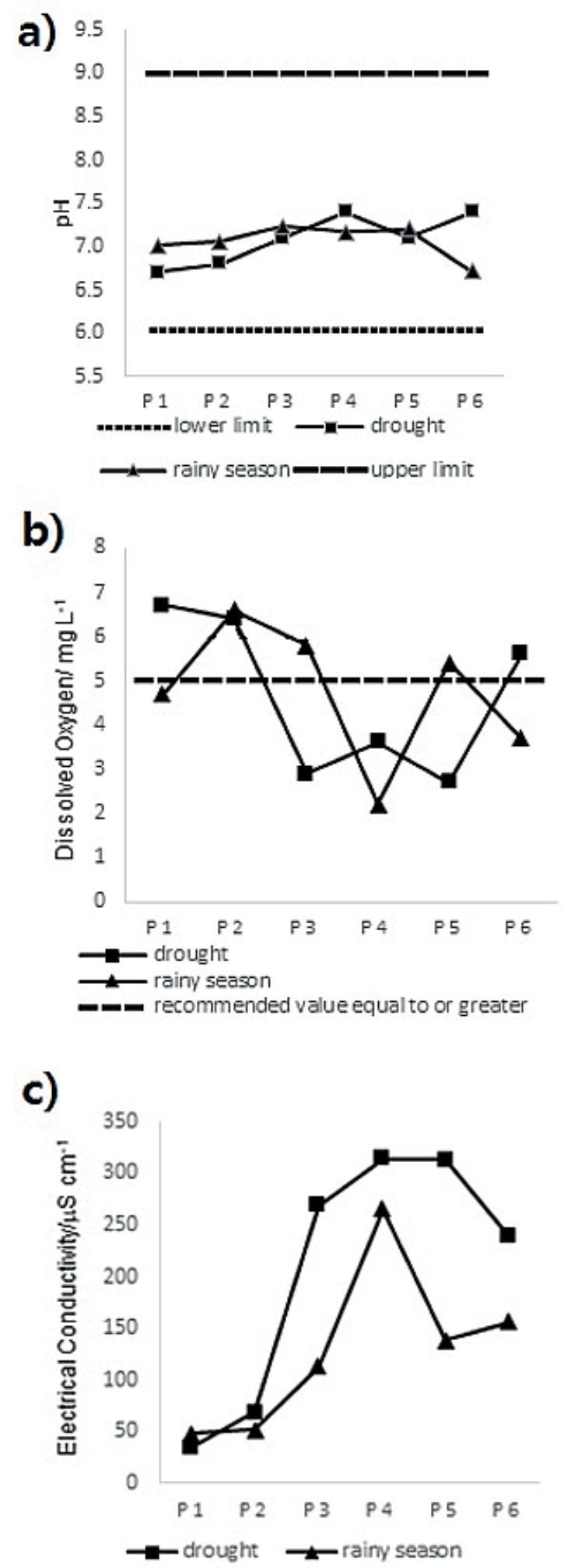

Figure 2 - Physical and chemical parameters: a) $\mathrm{pH}$, b) dissolved oxygen, c) electrical conductivity for the water samples from the Todos os Santos River. 
the urban perimeter of Teófilo Otoni city (P-3 and $\mathrm{P}-4)$. In the dry season, the values at points P-3, P-4, P-5 and P-6 ranged from 239 to $314 \mu \mathrm{S} \mathrm{cm}^{-1}$. During the rainy season, these same points ranged from 113 to $265 \mu \mathrm{S} \mathrm{cm}^{-1}$. Therefore, $66.7 \%$ of the assessed points (P3 to P6) suggested anthropogenic changes in this parameter during the two seasons.

Regarding the physical and chemical parameters, the samples collected in both periods (i.e., drought and rainy) presented similar results for electrical conductivity and turbidity. For dissolved oxygen, similar results were found for locations 3 , 4 and 5 during the drought season.

The mean values of trace elements analyzed during the dry and rainy seasons are showed in Tables I and II. It can be seen that the elements aluminum, iron, and phosphorus were above those permitted by local regulations during both periods.

During the dry season, changes in the $\mathrm{Al}$ and Fe levels may be due to the inappropriate disposal of solid wastes, which can be observed along the route of the river; alternatively, these elements may be characteristic of the soil in this region. Lixiviation may also be considered given the high concentrations of aluminum. Elevated levels of $\mathrm{P}$ are related to domestic waste dumps in the riverbed (Christophoridis et al. 2009) as well as fertilizer used near the river (Rothwell et al. 2011).

In the rainy season, excessive levels of Ni were found. This may have been caused by industrial activities in the region (ATSDR 2005) and even the use of agricultural fertilizers contaminated by this metal (Campos et al. 2005), causing significant amounts of these contaminants to be eliminated in the river.

Matlab software was used to discover principal components (PCs) on water metal concentration series. Table III presented all the PCA eigenvalues for these water metals, and Table IV showed the corresponding principal component loadings. According to Table III, two PCs were selected and the first principal component (PC1) was a measure of all elements less than $\mathrm{Cr}, \mathrm{Ni}, \mathrm{Se}, \mathrm{Ag}$ and $\mathrm{Hg}$ which are indicative of primary contaminants; the second principal component (PC2) was primarily attributed to all elements less than $\mathrm{Cd}, \mathrm{Na}, \mathrm{Be}, \mathrm{Hg}, \mathrm{Ag}, \mathrm{Ta}, \mathrm{Ga}$, $\mathrm{Bi}, \mathrm{In}, \mathrm{Fe}, \mathrm{P}$ and $\mathrm{S}$ which is indicative of a second contaminant. In this way, the dataset resulted in two PCs, explaining $47.05 \%$ of the variance. These two independent principal components seemed to dominate the contamination data.

We performed an exploratory analysis using principal components analysis (PCA) and hierarchical cluster analysis (HCA), as shown in Fig. 3, in which the letters identify the collection month (i.e., A, May; B, June; C, July; D, September; and E, December). Fourteen principal components explained $96.2 \%$ of the variance. The PC1 and PC2 components accumulated the higher variances and were used for the differentiation of samples from the collection sites. The other components of accumulated minor variances were not enough to differentiate samples from collection sites. Thus, the sample in the PCA was grouped into six groups (G1 to G6). In this way, we can identify whether the samples collected in the month of December exhibited any similarities, as indicated by their position at the top (i.e., positive) part of $\mathrm{PC} 2$, which explained $12.5 \%$ of the total variance, and the left (i.e., negative) part of $\mathrm{PC} 1$, which explained $34.6 \%$.

However, the samples lying at the bottom (i.e., negative) part of $\mathrm{PC} 2$ and the negative part of PC1 exhibit similarities across several months of collection, such as the samples from location 1 in the months of May, June, July, and September. Samples from area 2 came in this quadrant in the months of May, June, and September. From location 3, only the sample collected in July was in this quadrant; from location 4 , the samples from June and September were similar to the points above and from area 6, only the sample collected in September was in that quadrant. Considering the arrangement of the samples with positive scores for both PC1 and PC2, the samples that most closely resemble each other are the ones from location 
TABLE I

Mean values of trace element concentrations in water samples during the dry season (sample concentration \pm standard deviation in $\mu \mathrm{g} \mathrm{L}^{-1}$ ). $\mathrm{RMV}$ in $\mu \mathrm{g} \mathrm{L}^{-1}$ (Recommended Maximum values according to CONAMA 2005).

\begin{tabular}{|c|c|c|c|c|c|c|c|}
\hline \multirow{2}{*}{ Elements } & \multicolumn{7}{|c|}{ Collecting Points } \\
\hline & P-1 & $\mathrm{P}-2$ & $\mathrm{P}-3$ & P-4 & P-5 & P-6 & RMV \\
\hline $\mathrm{Ag}$ & $1.640 \pm 0.178$ & $0.973 \pm 0.167$ & $0.431 \pm 0.062$ & $0.379 \pm 0.038$ & $0.104 \pm 0.014$ & $0.128 \pm 0.051$ & 10.000 \\
\hline $\mathrm{Al}$ & $27.870 \pm 4.160$ & $\begin{array}{c}* 455.280 \pm \\
24.050\end{array}$ & $\begin{array}{c}* 447.080 \pm \\
78.960\end{array}$ & $\begin{array}{c}* 233.950 \pm \\
19.690\end{array}$ & $\begin{array}{c}* 721.530 \pm \\
182.150\end{array}$ & $\begin{array}{c}689.970 \pm \\
73.900\end{array}$ & 100.000 \\
\hline As & $0.156 \pm 0.038$ & $0.173 \pm 0.051$ & $0.289 \pm 0.088$ & $0.342 \pm 0.082$ & $0.516 \pm 0.121$ & $0.334 \pm 0.066$ & 10.000 \\
\hline $\mathrm{Ba}$ & $20.540 \pm 0.253$ & $33.540 \pm 0.375$ & $36.510 \pm 2.362$ & $63.430 \pm 9.676$ & $56.060 \pm 4.595$ & $40.220 \pm 0.407$ & 700.000 \\
\hline $\mathrm{Be}$ & $0.001 \pm 0.000$ & $0.064 \pm 0.068$ & $0.078 \pm 0.048$ & $0.032 \pm 0.120$ & $0.411 \pm 0.203$ & $0.642 \pm 0.140$ & 40.000 \\
\hline $\mathrm{Bi}$ & $0.011 \pm 0.004$ & $0.016 \pm 0.006$ & $0.020 \pm 0.007$ & $0.013 \pm 0.006$ & $0.020 \pm 0.005$ & $0.023 \pm 0.004$ & \\
\hline $\mathrm{Ca}$ & $\begin{array}{c}897.000 \pm \\
86.000\end{array}$ & $\begin{array}{c}2762.000 \pm \\
239.000\end{array}$ & $\begin{array}{c}11045.000 \pm \\
654.000\end{array}$ & $\begin{array}{c}12655.000 \pm \\
766.000\end{array}$ & $\begin{array}{c}13158.000 \pm \\
171.000\end{array}$ & $\begin{array}{c}8629.000 \pm \\
347.000\end{array}$ & \\
\hline $\mathrm{Cd}$ & $0.001 \pm 0.003$ & $0.005 \pm 0.011$ & $0.014 \pm 0.005$ & $0.017 \pm 0.007$ & $0.024 \pm 0.013$ & $0.016 \pm 0.062$ & 1.000 \\
\hline Co & $0.018 \pm 0.007$ & $0.061 \pm 0.010$ & $0.432 \pm 0.043$ & $0.353 \pm 0.031$ & $0.329 \pm 0.046$ & $0.231 \pm 0.012$ & 50.000 \\
\hline $\mathrm{Cs}$ & $0.258 \pm 0.006$ & $0.302 \pm 0.010$ & $0.239 \pm 0.023$ & $0.270 \pm 0.012$ & $0.290 \pm 0.034$ & $0.218 \pm 0.016$ & \\
\hline $\mathrm{Cu}$ & $0.139 \pm 0.028$ & $0.162 \pm 0.045$ & $1.600 \pm 0.060$ & $0.656 \pm 0.050$ & $1.190 \pm 0.247$ & $7.357 \pm 0.043$ & 9.000 \\
\hline $\mathrm{Fe}$ & $\begin{array}{c}* 881.200 \pm \\
1.200\end{array}$ & $\begin{array}{c}* 1281.700 \pm \\
2.100\end{array}$ & $\begin{array}{c}* 2484.300 \pm \\
2.200\end{array}$ & $\begin{array}{c}* 3425.900 \pm \\
1.700\end{array}$ & $\begin{array}{c}* 5945.600 \pm \\
1.600\end{array}$ & $\begin{array}{c}* 3239.300 \pm \\
1.700\end{array}$ & 300.000 \\
\hline $\mathrm{Ga}$ & $0.528 \pm 0.029$ & $1.013 \pm 0.048$ & $1.079 \pm 0.087$ & $1.632 \pm 0.054$ & $1.900 \pm 0.211$ & $1.376 \pm 0.068$ & \\
\hline $\mathrm{Hg}$ & $0.027 \pm 0.008$ & $0.019 \pm 0.003$ & $0.003 \pm 0.011$ & $0.031 \pm 0.005$ & $0.012 \pm 0.004$ & $0.017 \pm 0.002$ & 0.200 \\
\hline In & $0.006 \pm 0.003$ & $0.005 \pm 0.001$ & $0.006 \pm 0.002$ & $0.006 \pm 0.001$ & $0.005 \pm 0.001$ & $0.006 \pm 0.003$ & \\
\hline $\mathrm{K}$ & $\begin{array}{c}357.000 \pm \\
8.000\end{array}$ & $\begin{array}{c}1106.000 \pm \\
64.000\end{array}$ & $\begin{array}{c}4565.000 \pm \\
506.000\end{array}$ & $\begin{array}{c}5360.000 \pm \\
157.000\end{array}$ & $\begin{array}{c}6759.000 \pm \\
849.000\end{array}$ & $\begin{array}{c}5834.000 \pm \\
193.000\end{array}$ & \\
\hline $\mathrm{Li}$ & $0.309 \pm 0.144$ & $0.475 \pm 0.181$ & $1.008 \pm 0.280$ & $\begin{array}{c}345.974 \pm \\
0.948\end{array}$ & $2.568 \pm 0.211$ & $2.478 \pm 0.093$ & 2500.000 \\
\hline $\mathrm{Mn}$ & $15.720 \pm 0.210$ & $28.880 \pm 1.360$ & $66.040 \pm 2.490$ & $\begin{array}{c}134.000 \pm \\
4.110\end{array}$ & $\begin{array}{c}181.670 \pm \\
15.800\end{array}$ & $70.220 \pm 1.940$ & 100.000 \\
\hline $\mathrm{Na}$ & $\begin{array}{c}2033.000 \pm \\
70.000\end{array}$ & $\begin{array}{c}3345.000 \pm \\
182.000\end{array}$ & $\begin{array}{c}12525.000 \pm \\
1690.000\end{array}$ & $\begin{array}{c}15892.000 \pm \\
808.000\end{array}$ & $\begin{array}{c}17228.000 \pm \\
2684.000\end{array}$ & $\begin{array}{c}23958.000 \pm \\
587.000\end{array}$ & \\
\hline $\mathrm{Ni}$ & $0.280 \pm 0.410$ & $0.910 \pm 0.058$ & $1.780 \pm 0.132$ & $1.810 \pm 0.154$ & $1.140 \pm 0.140$ & $1.510 \pm 0.099$ & 25.000 \\
\hline $\mathrm{P}$ & $\begin{array}{c}* 25.800 \pm \\
10.810\end{array}$ & $\begin{array}{c}* 103.600 \pm \\
11.100\end{array}$ & $\begin{array}{c}* 841.900 \pm \\
24.800\end{array}$ & $\begin{array}{c}* 612.730 \pm \\
14.178\end{array}$ & $\begin{array}{c}* 1167.590 \pm \\
24.600\end{array}$ & $\begin{array}{c}* 269.030 \pm \\
15.110\end{array}$ & 20.000 \\
\hline $\mathrm{Pb}$ & $0.018 \pm 0.013$ & $0.098 \pm 0.015$ & $2.175 \pm 0.176$ & $3.670 \pm 0.090$ & $2.014 \pm 0.270$ & $0.875 \pm 0.250$ & 10.000 \\
\hline S & $\begin{array}{c}281.800 \pm \\
141.200\end{array}$ & $\begin{array}{c}281.400 \pm \\
68.400\end{array}$ & $\begin{array}{c}417.500 \pm \\
57.580\end{array}$ & $\begin{array}{c}412.200 \pm \\
80.300\end{array}$ & $\begin{array}{c}366.945 \pm \\
70.600\end{array}$ & $\begin{array}{c}294.200 \pm \\
92.130\end{array}$ & \\
\hline $\mathrm{Se}$ & $1.145 \pm 1.481$ & $0.962 \pm 1.546$ & $0.564 \pm 0.161$ & $2.146 \pm 1.411$ & $1.592 \pm 1.157$ & $0.543 \pm 1.452$ & 10.000 \\
\hline $\mathrm{Si}$ & $\begin{array}{c}3585.000 \pm \\
128.000\end{array}$ & $\begin{array}{c}4873.000 \pm \\
120.000\end{array}$ & $\begin{array}{c}8499.000 \pm \\
155.000\end{array}$ & $\begin{array}{c}10299.000 \pm \\
211.000\end{array}$ & $\begin{array}{c}9502.000 \pm \\
223.000\end{array}$ & $\begin{array}{c}10699.000 \pm \\
287.000\end{array}$ & \\
\hline $\mathrm{Sr}$ & $14.970 \pm 0.152$ & $28.994 \pm 0.397$ & $62.250 \pm 2.020$ & $82.570 \pm 1.600$ & $73.370 \pm 4.500$ & $43.050 \pm 0.817$ & \\
\hline $\mathrm{T} \ell$ & $0.015 \pm 0.004$ & $0.044 \pm 0.008$ & $0.017 \pm 0.002$ & $0.027 \pm 0.006$ & $0.015 \pm 0.004$ & $0.015 \pm 0.005$ & \\
\hline $\mathrm{U}$ & $0.004 \pm 0.005$ & $0.116 \pm 0.020$ & $0.096 \pm 0.016$ & $0.191 \pm 0.015$ & $0.163 \pm 0.040$ & $0.192 \pm 0.023$ & 20.000 \\
\hline V & $0.031 \pm 0.002$ & $0.883 \pm 0.026$ & $0.748 \pm 0.088$ & $1.679 \pm 0.079$ & $2.059 \pm 0.343$ & $1.598 \pm 0.295$ & 100.000 \\
\hline W & $0.025 \pm 0.005$ & $0.012 \pm 0.003$ & $0.057 \pm 0.003$ & $0.018 \pm 0.008$ & $0.035 \pm 0.014$ & $0.020 \pm 0.008$ & \\
\hline $\mathrm{Zn}$ & $3.460 \pm 0.233$ & $9.086 \pm 0.174$ & $26.180 \pm 1.760$ & $19.825 \pm 0.508$ & $14.558 \pm 1.22$ & $8.107 \pm 0.285$ & 180.000 \\
\hline
\end{tabular}

*Above the maximum value permitted by Resolution 357 of CONAMA/2005. 
TABLE II

Mean values of trace elements in water samples during the rainy season (sample concentration \pm standard deviation in $\mu \mathrm{g}$ $\mathrm{L}^{-1}$ ). RMV in $\mu \mathrm{g} \mathrm{L}^{-1}$ (Recommended Maximum Values according to CONAMA 2005).

\begin{tabular}{|c|c|c|c|c|c|c|c|}
\hline \multirow{2}{*}{ Elements } & \multicolumn{7}{|c|}{ Collecting Points } \\
\hline & P-1 & P-2 & $\mathrm{P}-3$ & P-4 & P-5 & P-6 & RMV \\
\hline $\mathrm{Ag}$ & $0.039 \pm 0.073$ & $0.043 \pm 0.068$ & ND & ND & ND & ND & 10.000 \\
\hline $\mathrm{Al}$ & $\begin{array}{c}* 109.080 \pm \\
0.857\end{array}$ & $\begin{array}{c}* 244.890 \pm \\
9.253\end{array}$ & $\begin{array}{c}* 272.520 \pm \\
20.550\end{array}$ & $\begin{array}{c}* 768.890 \pm \\
49.930\end{array}$ & $\begin{array}{c}* 600.700 \pm \\
33.280\end{array}$ & $\begin{array}{c}* 2831.800 \pm \\
141.900\end{array}$ & 100.000 \\
\hline As & $0.025 \pm 0.191$ & ND & ND & $0.275 \pm 0.169$ & $0.315 \pm 0.173$ & $0.715 \pm 0.193$ & 10.000 \\
\hline $\mathrm{Ba}$ & $27.451 \pm 0.099$ & $28.705 \pm 0.266$ & $29.408 \pm 0.681$ & $83.411 \pm 1.338$ & $43.042 \pm 0.583$ & $73.350 \pm 1.111$ & 700.000 \\
\hline $\mathrm{Be}$ & $0.001 \pm 0.000$ & $0.009 \pm 0.004$ & $0.078 \pm 0.032$ & $0.022 \pm 0.060$ & $0.632 \pm 0.109$ & $0.511 \pm 0.073$ & 40.000 \\
\hline $\mathrm{Bi}$ & ND & ND & ND & ND & ND & ND & \\
\hline $\mathrm{Ca}$ & $\begin{array}{c}1569.000 \pm \\
98.000\end{array}$ & $\begin{array}{c}1642.000 \pm \\
79.000\end{array}$ & $\begin{array}{c}3714.000 \pm \\
126.000\end{array}$ & $\begin{array}{c}8913.000 \pm \\
74.000\end{array}$ & $\begin{array}{c}5004.000 \pm \\
55.000\end{array}$ & $\begin{array}{c}4440.830 \pm \\
121.870\end{array}$ & \\
\hline $\mathrm{Cd}$ & ND & ND & ND & ND & ND & ND & 1.000 \\
\hline Co & $0.027 \pm 0.036$ & ND & ND & $0.173 \pm 0.070$ & $0.001 \pm 0.039$ & $0.317 \pm 0.039$ & 50.000 \\
\hline Cs & $0.370 \pm 0.021$ & $0.328 \pm 0.064$ & $0.120 \pm 0.011$ & $0.217 \pm 0.044$ & $0.096 \pm 0.035$ & $0.435 \pm 0.102$ & \\
\hline $\mathrm{Cu}$ & $3.767 \pm 0.261$ & $0.657 \pm 0.155$ & $7.672 \pm 0.195$ & $1.758 \pm 0.025$ & $7.368 \pm 1.262$ & $5.775 \pm 0.313$ & 9.000 \\
\hline $\mathrm{Fe}$ & $\begin{array}{c}* 1217.390 \pm \\
0.010\end{array}$ & $\begin{array}{c}* 570.050 \pm \\
0.020\end{array}$ & $\begin{array}{c}193.240 \\
\pm 0.100\end{array}$ & $\begin{array}{c}231.880 \\
\pm 0.300\end{array}$ & $\begin{array}{c}188.410 \\
\pm 1.100\end{array}$ & $\begin{array}{c}* 1043.480 \pm \\
3.200\end{array}$ & 300.000 \\
\hline $\mathrm{Ga}$ & $0.032 \pm 0.016$ & $0.856 \pm 0.041$ & $0.996 \pm 0.054$ & $1.456 \pm 0.048$ & $1.698 \pm 0.113$ & $1.859 \pm 0.055$ & \\
\hline $\mathrm{Hg}$ & $0.001 \pm 0.000$ & $0.011 \pm 0.001$ & $0.001 \pm 0.000$ & $0.057 \pm 0.004$ & $0.007 \pm 0.001$ & $0.013 \pm 0.001$ & 0.200 \\
\hline In & $0.003 \pm 0.000$ & $0.002 \pm 0.000$ & $0.002 \pm 0.000$ & $0.003 \pm 0.000$ & $0.001 \pm 0.000$ & $0.005 \pm 0.000$ & \\
\hline $\mathrm{K}$ & $\begin{array}{c}1753.000 \pm \\
11.000\end{array}$ & $\begin{array}{c}2217.000 \pm \\
9.000\end{array}$ & $\begin{array}{c}2022.000 \pm \\
18.000\end{array}$ & $\begin{array}{c}3714.000 \pm \\
101.000\end{array}$ & $\begin{array}{c}2520.000 \pm \\
67.000\end{array}$ & $\begin{array}{c}3259.000 \pm \\
20.000\end{array}$ & \\
\hline $\mathrm{Li}$ & $7.420 \pm 0.241$ & $0.000 \pm 0.000$ & $0.340 \pm 0.244$ & $0.577 \pm 0.372$ & $0.605 \pm 0.456$ & $2.023 \pm 0.085$ & 2500.000 \\
\hline $\mathrm{Mn}$ & $25.785 \pm 0.452$ & $6.281 \pm 0.151$ & $5.209 \pm 0.119$ & $78.914 \pm 2.314$ & $13.912 \pm 0.236$ & $52.151 \pm 1.353$ & 100.000 \\
\hline $\mathrm{Na}$ & $\begin{array}{c}426.000 \pm \\
10.000\end{array}$ & $\begin{array}{c}480.000 \pm \\
4.000\end{array}$ & $\begin{array}{c}1084.000 \pm \\
28.000\end{array}$ & $\begin{array}{c}2433.000 \pm \\
16.000\end{array}$ & $\begin{array}{c}1143.000 \pm \\
15.000\end{array}$ & $\begin{array}{c}1397.000 \pm \\
8.000\end{array}$ & \\
\hline $\mathrm{Ni}$ & $\begin{array}{c}* 90.701 \pm \\
1.637\end{array}$ & $11.172 \pm 0.303$ & $9.853 \pm 0.243$ & $10.413 \pm 0.207$ & $23.843 \pm 0.526$ & $\begin{array}{c}* 31.316 \pm \\
0.330\end{array}$ & 25.000 \\
\hline $\mathrm{P}$ & $\begin{array}{c}* 61.750 \pm \\
8.940\end{array}$ & $\begin{array}{c}* 31.960 \pm \\
7.680\end{array}$ & $\begin{array}{c}* 183.250 \pm \\
12.770\end{array}$ & $\begin{array}{c}* 461.590 \pm \\
17.470\end{array}$ & $\begin{array}{c}* 164.420 \pm \\
14.400\end{array}$ & $\begin{array}{c}* 192.310 \pm \\
14.160\end{array}$ & 20.000 \\
\hline $\mathrm{Pb}$ & ND & ND & ND & $2.547 \pm 0.217$ & $0.186 \pm 0.064$ & ND & 10.000 \\
\hline $\mathrm{S}$ & $\begin{array}{c}217.400 \pm \\
100.400\end{array}$ & $\begin{array}{c}211.100 \pm \\
45.800\end{array}$ & $\begin{array}{c}395.300 \pm \\
36.440\end{array}$ & $\begin{array}{c}441.260 \pm \\
90.670\end{array}$ & $\begin{array}{c}321.820 \pm \\
62.080\end{array}$ & $\begin{array}{c}276.320 \pm \\
73.130\end{array}$ & \\
\hline $\mathrm{Se}$ & $0.494 \pm 2.381$ & $1.591 \pm 0.934$ & $1.644 \pm 1.545$ & $2.507 \pm 2.603$ & $0.987 \pm 2.023$ & $1.811 \pm 0.412$ & 10.000 \\
\hline $\mathrm{Si}$ & $4087 \pm 31$ & $4358 \pm 24$ & $5209 \pm 893$ & $6673 \pm 91$ & $6854 \pm 944$ & $9984 \pm 188$ & \\
\hline $\mathrm{Sr}$ & $21.520 \pm 0.044$ & $23.431 \pm 0.033$ & $44.827 \pm 0.665$ & $94.550 \pm 2.127$ & $66.943 \pm 1.090$ & $68.690 \pm 0.278$ & \\
\hline $\mathrm{Tl}$ & ND & $0.002 \pm 0.000$ & $0.001 \pm 0.000$ & $0.0000 \pm 0.00$ & ND & ND & \\
\hline $\mathrm{U}$ & ND & ND & ND & $0.227 \pm 0.005$ & $0.031 \pm 0.041$ & $0.448 \pm 0.144$ & 20.000 \\
\hline V & ND & ND & ND & $1.756 \pm 0.135$ & $1.084 \pm 0.111$ & $5.388 \pm 0.240$ & 100.000 \\
\hline W & $0.021 \pm 0.002$ & $0.009 \pm 0.007$ & $0.042 \pm 0.005$ & $0.023 \pm 0.012$ & $0.012 \pm 0.014$ & $0.006 \pm 0.001$ & \\
\hline $\mathrm{Zn}$ & $23.820 \pm 1.149$ & $8.862 \pm 0.464$ & $29.740 \pm 0.838$ & $40.170 \pm 0.655$ & $29.650 \pm 0.840$ & $17.320 \pm 0.375$ & 180.000 \\
\hline
\end{tabular}

*Above the maximum value permitted by Resolution 357 of CONAMA 2005. ND = Not detected (Below LOD). 
TABLE III

Eigenvalues of PCA for water metal analysis datasets.

\begin{tabular}{cccc}
\hline Component & Eigenvalue & Variance & $\begin{array}{c}\text { Cumulative } \\
\text { variance } \%\end{array}$ \\
\hline 1 & 10.375 & 34.585 & 34.585 \\
2 & 3.739 & 12.463 & 47.048 \\
3 & 3.216 & 10.719 & 57.767 \\
4 & 2.565 & 8.549 & 66.316 \\
5 & 1.859 & 6.196 & 72.512 \\
6 & 1.601 & 5.335 & 77.848 \\
7 & 1.293 & 4.311 & 82.159 \\
8 & 1.154 & 3.846 & 86.004 \\
9 & 0.850 & 2.835 & 88.839 \\
10 & 0.575 & 1.918 & 90.757 \\
11 & 0.479 & 1.595 & 92.353 \\
12 & 0.460 & 1.534 & 93.887 \\
13 & 0.395 & 1.318 & 95.205 \\
14 & 0.297 & 0.990 & 96.195 \\
\hline
\end{tabular}

3 collected in May, area 5 in June, location 6 in July and location 4 in May. Regarding the samples with negative values of $\mathrm{PC} 1$ and positive values of PC2, this group of samples comprises those from point 2 collected in July, location 3 in June and September, area 4 in July, location 5 in May, July, and September and point 6 in July.

This distribution of water samples collected at different locations and in different months is explained by influences on the elemental content, as represented in the graph of weights (Fig. 4). In the positive region of $\mathrm{PC} 2$ and negative region of $\mathrm{PC} 1$, the elements that have the strongest influence are $\mathrm{Ni}, \mathrm{Cr}$, and $\mathrm{Se}$. The influence of $\mathrm{Ag}, \mathrm{Hg}$, and $\mathrm{In}$ is strong in the region in which both $\mathrm{PC} 1$ and $\mathrm{PC} 2$ are negative. When $\mathrm{PC} 1$ and $\mathrm{PC} 2$ are both positive, the elements $\mathrm{Cu}, \mathrm{Li}, \mathrm{Ce}, \mathrm{Zn}, \mathrm{Al}, \mathrm{Sr}, \mathrm{Ba}, \mathrm{Ur}, \mathrm{Va}, \mathrm{As}$, $\mathrm{Pb}, \mathrm{K}, \mathrm{Co}, \mathrm{Ca}$ and $\mathrm{Mn}$ stand out. For the region in which $\mathrm{PC} 2$ is negative and $\mathrm{PC} 1$ is positive, clustering is due to the levels of $\mathrm{Be}, \mathrm{Na}, \mathrm{Cd}, \mathrm{P}, \mathrm{Fe}$, $\mathrm{Ta}, \mathrm{Bi}, \mathrm{Ga}$ and $\mathrm{S}$.

\section{CONCLUSIONS}

The levels of dissolved oxygen during the dry and rainy period were in desagreement with the local regulations for points $3,4,5$. The electrical conductivity of TSR exhibited high values in both seasons for points 3 and 4 .

During the dry season the metals aluminum (points 2, 3, 4, 5) and iron (points 1-6) are outside the range permitted. For rainy season, aluminum (points 1-6), iron (points 1, 2, 6) and nickel (points 1, 6) exhibited high levels. The nonmetal phosphorus was found in disagreement with the legislation in the 6 points analysed for both seasons.

TABLE IV

Data for principal components 1 and 2 of the water analysis datasets.

\begin{tabular}{|c|c|c|}
\hline Components & PC1 & PC2 \\
\hline $\mathrm{Cr}$ & -0.113 & 0.4183 \\
\hline $\mathrm{Mn}$ & 0.270 & 0.0062 \\
\hline Co & 0.260 & 0.0301 \\
\hline $\mathrm{Cu}$ & 0.025 & 0.1855 \\
\hline $\mathrm{Pb}$ & 0.223 & 0.0269 \\
\hline $\mathrm{Cd}$ & 0.248 & -0.0140 \\
\hline $\mathrm{Li}$ & 0.075 & 0.1542 \\
\hline $\mathrm{Al}$ & 0.162 & 0.2544 \\
\hline $\mathrm{Na}$ & 0.180 & -0.1006 \\
\hline $\mathrm{Ba}$ & 0.216 & 0.1750 \\
\hline $\mathrm{K}$ & 0.241 & 0.0298 \\
\hline As & 0.245 & 0.1077 \\
\hline $\mathrm{Be}$ & 0.110 & -0.0155 \\
\hline $\mathrm{Hg}$ & -0.060 & -0.1735 \\
\hline $\mathrm{Ni}$ & -0.081 & 0.3595 \\
\hline $\mathrm{Ag}$ & -0.060 & -0.1574 \\
\hline $\mathrm{Se}$ & -0.042 & 0.0191 \\
\hline $\mathrm{Ta}$ & 0.100 & -0.2274 \\
\hline $\mathrm{Ur}$ & 0.217 & 0.1388 \\
\hline $\mathrm{Zn}$ & 0.117 & 0.2575 \\
\hline $\mathrm{Va}$ & 0.234 & 0.1902 \\
\hline $\mathrm{Ga}$ & 0.259 & -0.2083 \\
\hline $\mathrm{Sr}$ & 0.162 & 0.0764 \\
\hline $\mathrm{Bi}$ & 0.182 & -0.2222 \\
\hline $\mathrm{Ca}$ & 0.276 & 0.0223 \\
\hline $\mathrm{Ce}$ & 0.077 & 0.0616 \\
\hline In & -0.017 & -0.2016 \\
\hline $\mathrm{Fe}$ & 0.254 & -0.0866 \\
\hline $\mathrm{P}$ & 0.249 & -0.0244 \\
\hline S & 0.134 & -0.3704 \\
\hline
\end{tabular}




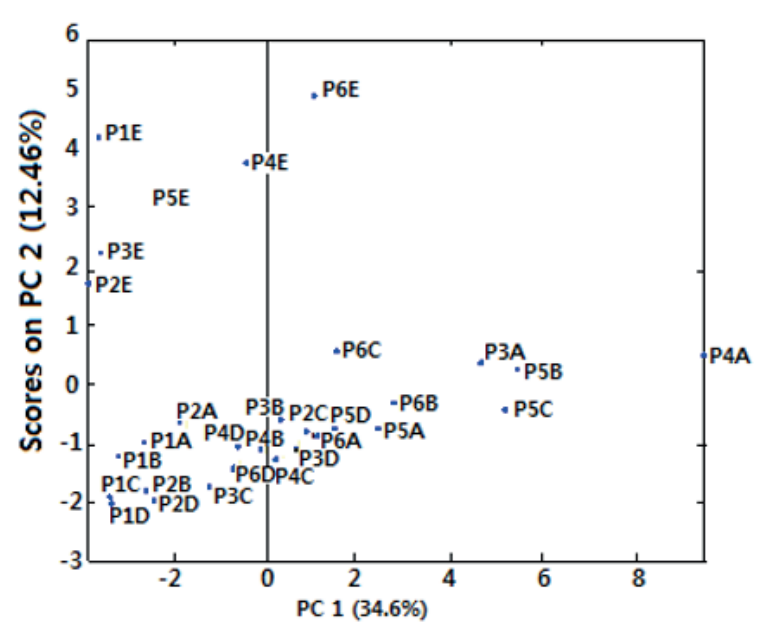

Figure 3 - Scores of water samples collected in different months based on the metal content of the Todos os Santos River.

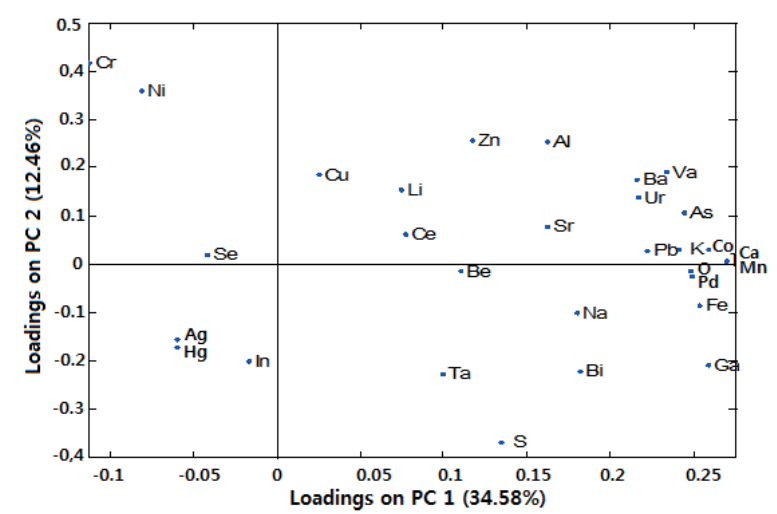

Figure 4 - Loadings representing the influence of different elements on spectroscopic readings of water samples collected at various locations along the Todos os Santos River.

Exploratory analysis using PCA and HCA demonstrated that are similarities among samples collected in different months at various locations, and together with the other dates, it can be suggest that TSR is facing a contamination problem that can influence the living beings that depends of this water source to survive.

\section{ACKNOWLEDGMENTS}

The authors are grateful to Fundação de Amparo à Pesquisa do Estado de Minas Gerais (FAPEMIG), Conselho Nacional de Desenvolvimento Científico e Tecnológico (CNPq), Fundação de Amparo à Pesquisa do Estado de São Paulo (FAPESP), Rede Mineira de Química (RQ-MG), Movimento Pró Rio Todos os Santos e Mucuri (MPRT SM) and Comitê de Bacia Hidrográfica do Rio Mucuri (CBH-MU1) for financial support and fellowships.

\section{REFERENCES}

ATSDR - AGENCY FOR TOXIC SUBSTANCES AND DISEASE REGISTRY. 2005. Toxicological Profile for Nickel. Available at: http://www.atsdr.cdc.gov/toxprofiles/ tp15.pdf. Accessed in 27/08/2015.

BLANC LR, MOREIRA FS, GONÇALVES AM, MANCHESTER RSS, BARONI L, FARIA MC DA S, BOMFETI CA, BARBOSA F AND RODRIGUES JL. 2014. Contamination in a Brazilian River: A Risk of Exposure to Untreated Effluents. J Environ Qual 42: 15961601.

CAMPOS MR, DA SILVA FN, NETO AEF, GUILHERME LRG, MARQUES JJ AND ANTUNES AS. 2005. Determination of cadmium, copper, chromium, nickel, lead and zinc in rock phosphates. Pesq Agropec Bras 40: 361-367.

CETESB - COMPANHIA AMBIENTAL DO ESTADO DE SÃO PAULO. 2001. Relatório de Qualidade das Águas Interiores do Estado de São Paulo. São Paulo, Brasil.

CETESB - COMPANHIA AMBIENTAL DO ESTADO DE SÃO PAULO. 2012. Guia Nacional de Coleta e Preservação de Amostras. Disponível em: http://laboratorios.cetesb. sp.gov.br/wp-content/uploads/sites/47/2013/11/guianacional-coleta-2012.pdf.

CHANG C AND LING Y. 2014. A water quality monitoring network design using fuzzy theory and multiple criteria analysis. Environ Monit Assess 186: 6459-6469.

CHIBA WAC, PASSERINI MD, BAIO JAF, TORRES JC AND TUNDISI JG. 2011. Seasonal study of contamination by metal in water and sediment in the subbasin in the southeast of Brazil. Braz J Biol 71: 833-843.

CHRISTOPHORIDIS C, DEDEPSIDIS D AND FYTIANOS K. 2009. Occurrence and distribution of selected heavy metals in the surface sediments of Thermaikos Gulf, N. Greece. Assessment using pollution indicators. J Hazard Mater 168: 1082-1091.

CONAMA - CONSELHO NACIONAL DO MEIO AMBIENTE. 2005. Resolução No. 357, Ministério do Meio Ambiente: Brasília, Brasil.

JORDÃO CP, RIBEIRO PR, MATOS AT AND FERNANDES RBA. 2007. Aquatic Contamination of the Turvo Limpo River Basin at the Minas Gerais State, Brazil. J Braz Chem Soc 18: 116-125. 
LAWRENCE MG, GREIG A, COLLERSON KD AND KAMBER BS. 2006. Direct quantification of rare earth element concentrations in natural waters by ICP-MS. Appl Geochem 21: 839-848.

OHE T, TATSUSHI W AND KEIJI W. 2004. Mutagens in surface waters: a review. Mutat Res-Rev Mutat 67: 109149.

REN S, MEE RW AND FRYMIER PD. 2004. Using factorial experiments to study the toxicity of metal mixtures. Ecotoxicol Environ Saf 59: 38-43.

REZENDE PS, MOURA PAS, DURÃO JR WA, NASCENTES CA, WINDMOLLER CC AND COSTA LM. 2011. Arsenic and Mercury Mobility in Brazilian Sediments from the São Francisco River Basin. J Braz Chem Soc 22: 910-918.

ROTHWELL JJ, DISE NB, TAYLOR KG, ALLOTT THE, SCHOLEFIELD P, DAVIES H AND NEAL C. 2011. A spatial and seasonal assessment of river water chemistry across north west England. Sci Total Environ 408: 841855.
SCALON MCS, RECHENMACHER C, SIEBEL AM, KAYSER ML, RODRIGUES MT, MALUF SW, RODRIGUES MAS AND DA SILVA LB. 2013. Genotoxic Potential and Physicochemical Parameters of Sinos River, Southern Brazil. Sci World J 2013: 1-7.

SIQUEIRA LFS, COSTA NETO JJG AND ROJAS MOAI. 2009. Determination of iron (II) in seawater by Fe system (II)/KSCN via UV-Vis spectrometry: a low-cost and practical alternative, Universidade Federal do Maranhão: São Luís, MA, Brasil.

VON SPERLING M. 1996. Introdução à Qualidade das Águas e ao Tratamento de Esgotos, $4^{\mathrm{a}}$ ed., Belo Horizonte: UFMG, $452 \mathrm{p}$.

WEBER P, BEHR ER, KNORR CL, VENDRUSCOLO DS, FLORES EMM, DRESSLER VL AND BALDISSEROTTO B. 2013. Metals in the water, sediment, and tissues of two fish species from different trophic levels in a subtropical Brazilian river. Microchem J 106: 61-66.

WHO - WORLD HEALTH ORGANIZATION. 2004. Guidelines for Drinking Water Quality, Geneva. 